\title{
The Cathedral of Vilnius: Problems and Features of Natural Conditions
}

\author{
Saulius Gadeikis ${ }^{1}$, Kastytis Dundulis ${ }^{2}$, Aistė Daukšytė ${ }^{3}$, Sonata Gadeikyte ${ }^{4}$ \\ Department of Hydrogeology and Engineering Geology, Faculty of Natural Sciences, \\ Vilnius University, Vilnius, Lithuania \\ E-mails: ${ }^{1}$ saulius.gadeikis@gf.vu.lt (correspondingauthor); ${ }^{2}$ kastytis.dundulis@gmail.com; \\ ${ }^{3}$ dauksyteaiste@gmail.com; ${ }^{4}$ sonata.gadeikyte@gf.vu.lt
}

\begin{abstract}
The Cathedral of Vilnius is one of the main architectural monuments in Lithuania. This structure was built in unfavourable geological conditions. Due to this reason, the foundation of the building subsides; there occur wall deformations and cracks. Preservation of the building is today's urgent problem. When evaluating the geologic environment from the perspective of engineering, construction works require deep analysis of the following key environment components and discuss them: relief, soils of geologic structure and their geotechnical properties, conditions of underground water occurrence and geological processes, and condition of the foundation. The article provides the brief history of construction and reconstruction of the Cathedral based on archival studies, the description of engineering geological conditions, and the archeologic and historic material of the evaluation of the foundation.
\end{abstract}

Keywords: Vilnius Cathedral, engineering geological conditions, foundation.

Conference topic: Geotechnical art and historical experience.

\section{Introduction}

The historic centre of Vilnius, the capital of Lithuania, is a state reservation of Vilnius Castles with remaining and preserved historic buildings of our capital, including the Cathedral, the Belfry, the Palace of the Grand Dukes of Lithuania, the Arsenal, the Upper Castle with Gediminas Tower, and a number of natural, cultural and archaeological monuments. This is a territory where the State of Lithuania has grown, expanded and existed; this is the centre of Vilnius development. This is also a part of the Old Town of Vilnius included in the UNESCO World Heritage List.

The Cathedral of Vilnius is one of the most impressive buildings in this architectural ensemble
(Fig. 1). Its history reaches back to the XIII century and relates with lords of our state and the most important historical events. The today's Cathedral seems stable and durable from outside, but since the very beginning of its construction there have been arising multiple problems related to deformations of the foundation and resulting wall cracks. The causes of such deformations are soils of the historical centre of Vilnius: they are of various geological origin and structure, they have various geotechnical characteristics, and level of ground water is very high besides, there are encountered geological and anthropogenic processes. The choice of the location of the Vilnius Cathedral was based on state and political interests. It should be noted that before the
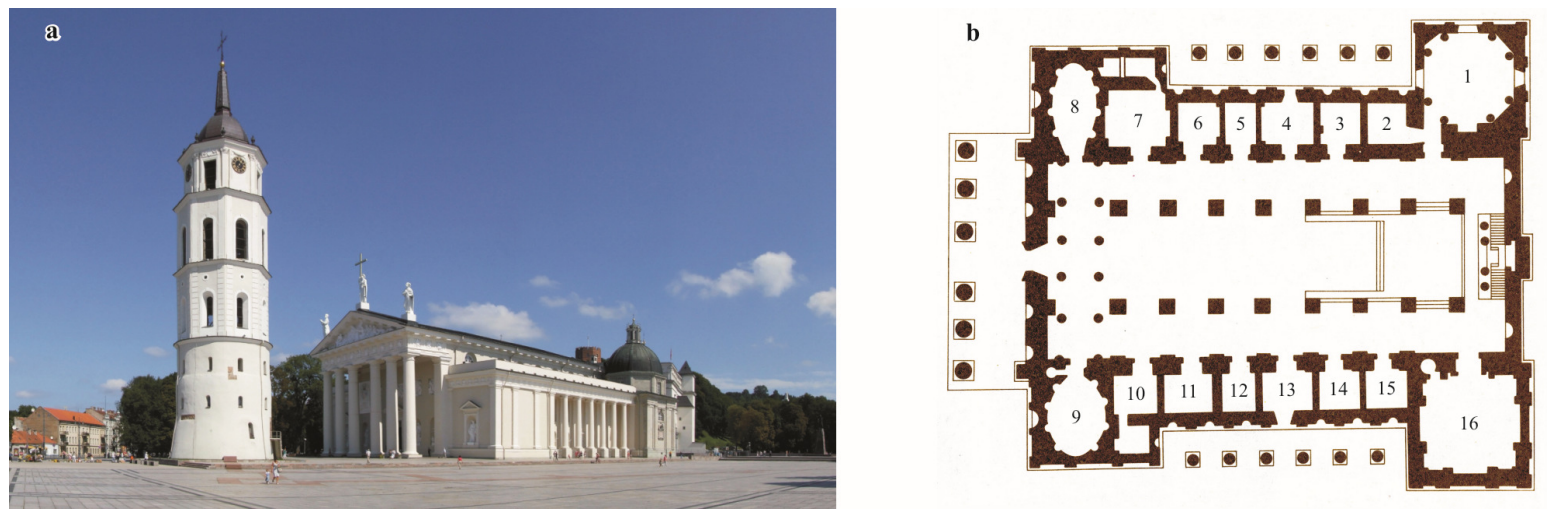

Fig. 1. Cathedral and its bell tower (a) (according to Turisto pasaulis 2016) and floor layout of the Cathedral (according to Kitkauskas 1989) (b): 1 - Sacristy, 2 - Stairs, 3 - St. Peter's Chapel, 4 - Northern Entrance (former the Kęsgailos II Chapel), 5 - the Saviour's Coffin Chapel, 6 - the Kęsgailos I Chapel, 7 - the Valavičiai (former The Old Royal Chapel) Chapel, 8 - St. Vladislovas Chapel, 9 - St. Virgin Mary Chapel (now Chapel of the Exiles auth.), 10 - Warehouse, 11 - the Goštautai Chapel, 12 - the Monvydai Chapel, 13 - Southern Entrance (former St. Trinity Chapel), 14 - supposed the Old Chapel of the Monvydai, 15 - Bishops' Chapel (now St. Sacrament), 16 - Kings' (now St. Kazimieras) Chapel

(C) 2016 The Authors. Published by VGTU Press. This is an open-access article distributed under the terms of the Creative Commons Attribution License, which permits unrestricted use, distribution, and reproduction in any medium, provided the original author and source are credited. 

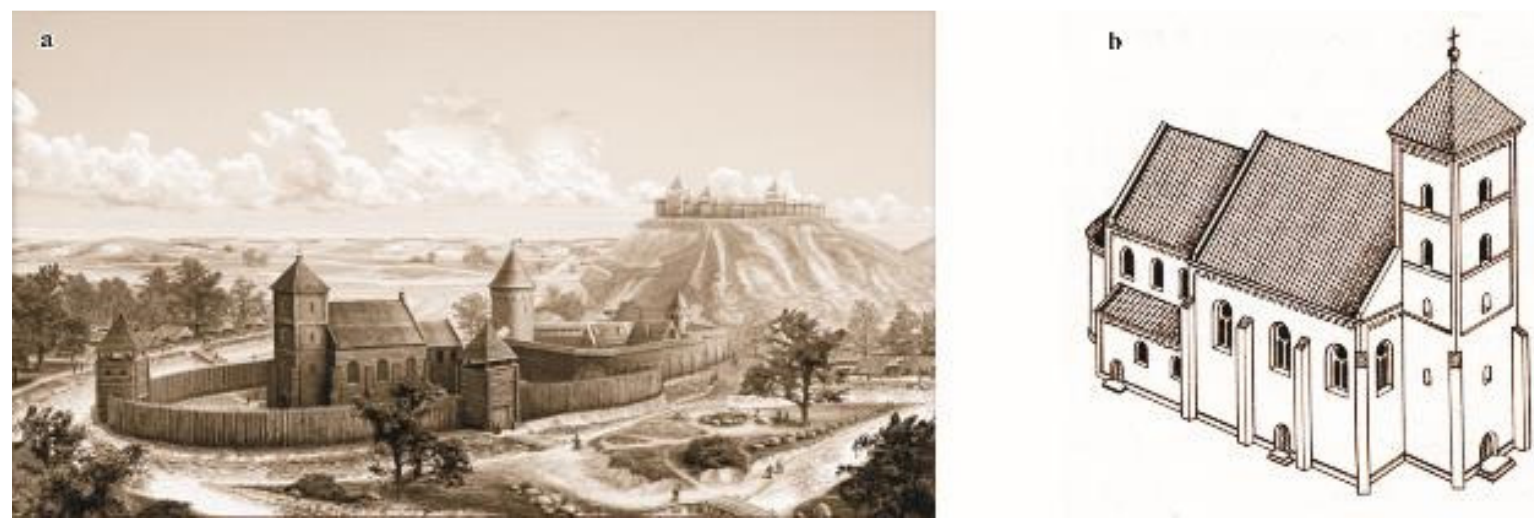

Fig. 2. Vilnius "Mindaugas Cathedral", the beg. of the XIII century (according to the reconstruction of artists, JSC "Metalo forma" 2016) (a) and the Cathedral from the North Western side, the XIII cent. (according to Kitkauskas 1989) (b)

second half of the XIX century the majority of building locations were decided without any consideration of the wholeness of natural environment of the area, especially one of its composite elements - geological environment. The latter component, namely, determines conditions of the building exploitation and durability.

Unfavourable conditions usually cause deformations of buildings, characteristic to the Cathedral of Vilnius.

To preserve the Cathedral and other adjacent historic buildings for the future, it is necessary to, first of all properly evaluate the ground of buildings, i.e. - engineering geological conditions. Historical, archeological and geological data presented below is based on works of historians, archaeologists V. Drema (1991), N. Kitkauskas (1989) and investigators, engineers geologists A. Pečkaitis (2004), K. Monstvilas (Montsvilas 1973, 1976; Montsvilas et al. 1995), prof. K. Dundulis (Dundulis, Trumpis 2015), quaternary geologists dr. J. Satkūnas et al. (2008), R. Guobytè (2007).

\section{Historical survey of construction and reconstruction of the Vilnius Cathedral}

Very little data on the first constructions of the Cathedral buildings have survived. The majority of information comes from archaeological excavations, annals, and archival documents of the city that remained. The first Cathedral was built in the middle of the XIII century. Its style was transiting from Romanic to Gothic; the layout was square, with three naves (Fig. 2).

The Cathedral reminds the first attempt to christen Lithuania in the middle of the XIII century, when the Lithuanians established their state and Mindaugas became the King of Lithuania. After the death of Mindaugas (1263), the Cathedral was turned into the pagans' temple.

Jogaila, the Great Duke of Lithuania, when getting married to Jadvyga, the heiress of the crown of Poland, obligated to turn to Christianity the last pagan country in Europe. In 1387, Jogaila started and finished within a year or two the construction of a new Gothic three-nave St. Stanislovas and St. Vladislovas Church with chapels, replacing the old pagan's temple (Fig. 3). In 1399, the Church was destroyed in fire. When rebuilt, the floor was lifted up at $20 \mathrm{~cm}$ from the existing level.

In 1419, the Cathedral burnt again. Vytautas, the Great Duke, built a new bigger Gothic cathedral in the place of the old one (Fig. 4). The Cathedral became the grave for the following persons: Ona, Vytautas wife (1418), Vytautas, the Great Duke of Lithuania (1430), Žygimantas Kęstutaitis, his brother (1440), Švitrigaila (1452), St. Kazimieras (1484), Aleksandras Jogailaitis, the Great Duke of Lithuania and King of Poland (1506), Queen Elžbieta Habsburgaite (1545) and Queen Barbora Radvilaite (1551), wives of Žygimantas Augustas the Great Duke of Lithuania and King of Poland. The Cathedral of Vilnius became a necropolis of many famous Lithuanian people - statesmen, bishops and canons.

A big fire ruined the Cathedral built by Vytautas in 1530 (Fig. 5). Its foundation and a part of walls have remained till nowadays.

Rebuilding of the Cathedral took around 25 years (1534-1557). The building itself was connected to the Palace of the Lower Castle with a gallery. The floor was lifted by $187 \mathrm{~cm}$ over the previous one. The Italian architects had already added features of Renaissance to the Cathedral before (Fig. 6); however, after several

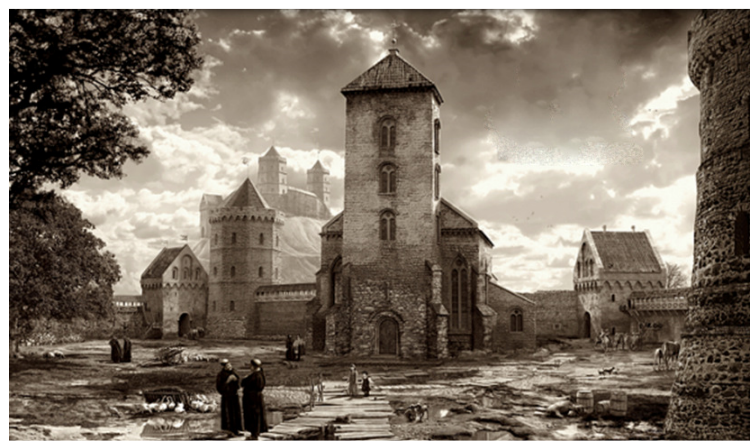

Fig. 3. Vilnius Cathedral. The end of the XIV century. (according to the reconstruction of artists, JSC "Metalo forma". Painting of Antanas Vaičekauskas, according to the reconstruction of Architecture historian N. Kitkauskas based on nature research. 3D graphic art - Vilius Petrauskas. 3D mock ups - Darius Galinis. Vilnius, 2009) 
a
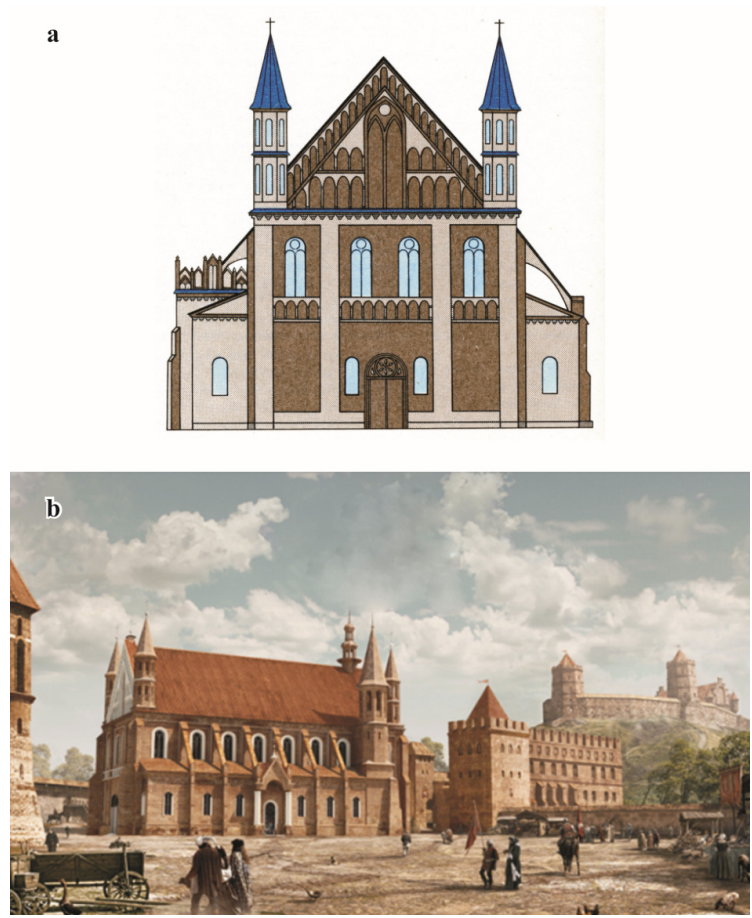

Fig. 4. The Cathedral after the fire of 1419 (reconstruction under Kitkauskas 1989) (a) and the beginning of the XVI century (according to the reconstruction of artists, JSC "Metalo forma" 2016) (b)

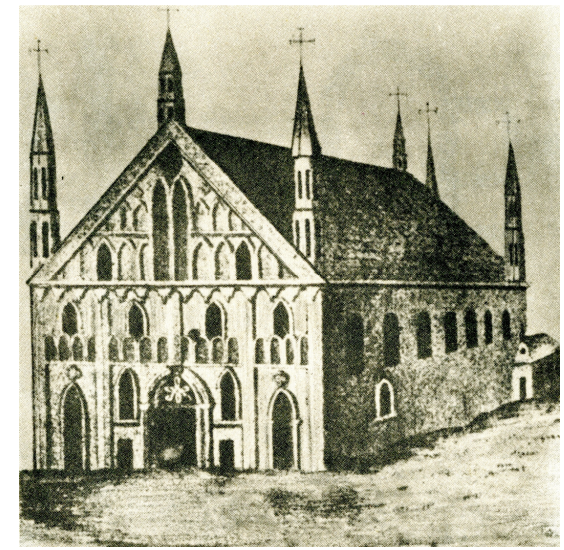

Fig. 5. The Cathedral before the fire of 1530 (Kitkauskas 1989)

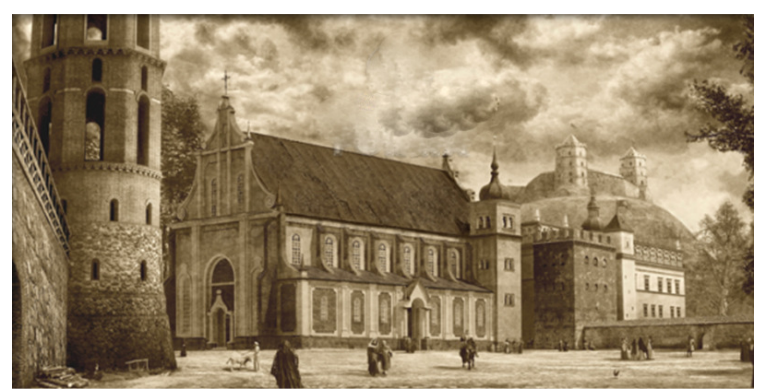

Fig. 6. Vilnius Cathedral. The end of the XVI century (according to the reconstruction of artists, JSC "Metalo forma" 2016) decades there occurred cracks in the walls. In 15961600, the Cathedral underwent repair again. Due to dangerous cracks, the western wall was rebuilt.

One more fire devastated the Cathedral again in 1610. Before 1632 the temple was rebuilt following Baroque features (archit. Vilhelmas Polis). A gallery was added to the eastern wall, and it connected the St. Kazimieras Chapel with the palace rooms. Under the St. Kazimieras Chapel, in 1648 there was buried the heart of Vladislovas, the King of Poland and Great Duke of Lithuania. At that time, water sewage canal to the Neris River was built.

In 1655-1661, Vilnius was conquered by the Army of Moscow. During this occupation, the Cathedral and other buildings of the Lower Castle suffered a lot, all inside equipment was lost, the church basements got under water due to debris in the Vilnia River. Repair of the Cathedral and St. Kazimieras Chapel continued till 1695.

The Swedish Army also caused much damage to the Cathedral in the beginning of the XVIII c. In 17091705 , the Cathedral was prolonged to the west, adding a new wall of the front façade on new foundation. After several decades the building got cracks again from vaults to basement.

In $1748-1750$, the Vilnia river-bed and canal is cleaned and undergrounds of the Cathedral are drained. Then it is noticed that the tower with the clock is cracking. Eventually, on 2 September, 1769, a big storm ruins the south western tower of the Cathedral. The tower falls on the Chapel named under Mary and kills 6 churchmen.

After this disaster, Bishop Ignotas Jokūbas Masalskis decides to significantly modernise the church. The court architect Martynas Knakfusas (Marcin Knackfus) inspects walls and foundation of the Cathedral, and in April of 1771 he executes a Deed of Defects. Here he indicates that "the building is under threat of collapse as its basement is covered with water due to clotted city sewage; thus, foundation has been severally ruined. The wooden piles supporting foundation have decayed, which has resulted in constant subsiding of the building". Summarising, M. Knakfusas first suggests letting down soil and canal waters from the foundation of the Cathedral, its basement and surroundings (Drema 1991).

The final project for the Cathedral reconstructions was prepared by Laurynas Stuoka Gucevičius in around 1781. Reconstruction works (with finishing) continued till 1801. After the death of the architect in 1798, his deeds were continued by the architect Martynas Sulcas (M. Szulc). Following the project of L. StuokaGucevičius, the central part of the building (internal walls, vaults of all three naves and supporting columns) were preserved. The St. Kazimieras and Royal (Valavičius') Chapels remained unchanged. The majority of changes were external: the northern and southern walls with columns were built, in different times these walls were integrated with chapels; there was built a sacristy (with a dome) in front of the Kazimieras' Chap- 
el; the western wall was rebuilt and a portico with 6 columns was built. New parts of the building were structured on the massive brick foundation, resting upon wooden poles $2.2 \div 2.5 \mathrm{~m}$ in length.

Overall, in 1783-1784, under the newly built parts of the building, there were placed 2082 piles made of alder, $7.8 \mathrm{~m}$ in length, and $1513.5 \mathrm{~m}$ of oak beams were laid on foundation of alder piles for joist ceiling. During 2 years of work, 0.5 billion of bricks of various sizes was used for the brick part of foundation, together with around 1500 boxes of lime and around 1200 boxes of gravel, hundreds of filed stones and bricks from ruined walls. 1100 cubic feet of Čiobiškis ashlars were also used for foundation (Drèma 1991). The Vilnius Cathedral was actually newly built and obtained spectacular, monumental shapes of the Classicism (Fig. 7).

In the middle of the XIX c. the southern side of the Cathedral changed significantly. New streets were built (now Gediminas Avenue, Maironio, L. Stuokos Gucevičiaus Streets and etc.). Even though there happened no big fires, the Cathedral was repaired in 1876 and 1883. There occurred more and more cracks in the walls and vaults. During the last repair foundation was also taken into consideration and taken care of. Having inspected the foundation, it was stated that the old building stands of solid foundation, still, the part built by L. Stuoka Gucevičius, resting on wooden piles, was in danger, since the piles were pretty cracky. In 1907, the portico cracked too. It was reinforced with beams, but the foundation remained untouched. No one and nobody took care of the Cathedral during the World War II and in the post-war years.

In the spring of 1931, during the flood of the Neris, the water level critically and instantly raised. On the 28 of April, 1931, the highest level water in the history of the city was measured - it reached $825 \mathrm{~cm}$. Such flood as in 1931 happens once in a century only. Water covered the Cathedral Square; undergrounds of Cathedral were flooded to the ceilings (Fig. 8).

The floor in the lateral nave and the St. Kazimieras Chapel hollowed, multiple cracks occurred in the walls and vaults, columns of the western portico leaned to the west. Measurements revealed that the centre of gravity of the portico columns moved from the vertical by $7 \mathrm{~cm}$. The foundation block of the portico columns cracked and divided into three pieces. Emergency status was announced and the Cathedral was closed for public.

On the 17 of July, 1931, the Vilnius Basilica Saving Committee was convened together with several special commissions (the key ones - Technical and Art Commissions). Leading future research and preserving works was assigned to Juliusas Klosas (Juliusz Kłos), his deputy for research was the architect Janas Pekša (Jan Peksza). From July of 1931 to the summer of 1932, there were geological researches performed, followed with measurements of the building, observations of the level of ground water and its ground. The floor was taken out from the middle of the building and 50 pits (up to $5 \div 8 \mathrm{~m}$ in depth) were dug. In 1932-1937, under management of eng. H. Wąsowicz invited from Warsaw, reinforcement of the Cathedral foundation and underground part of the building was performed. 279 piles of ferroconcrete, $11 \div 15 \mathrm{~m}$ in length, were established under the foundation (Fig. 9).

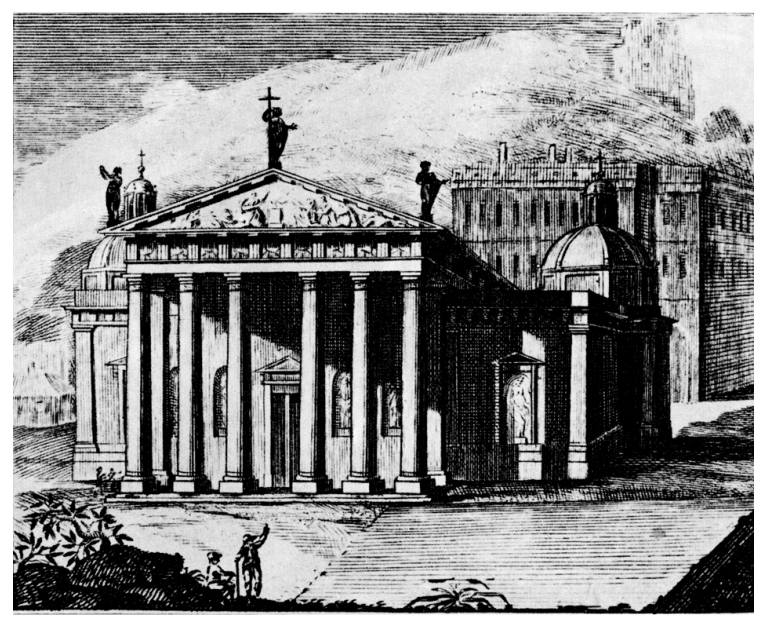

Fig. 7. View of the Cathedral in 1798 (acc. to Drema 1991)
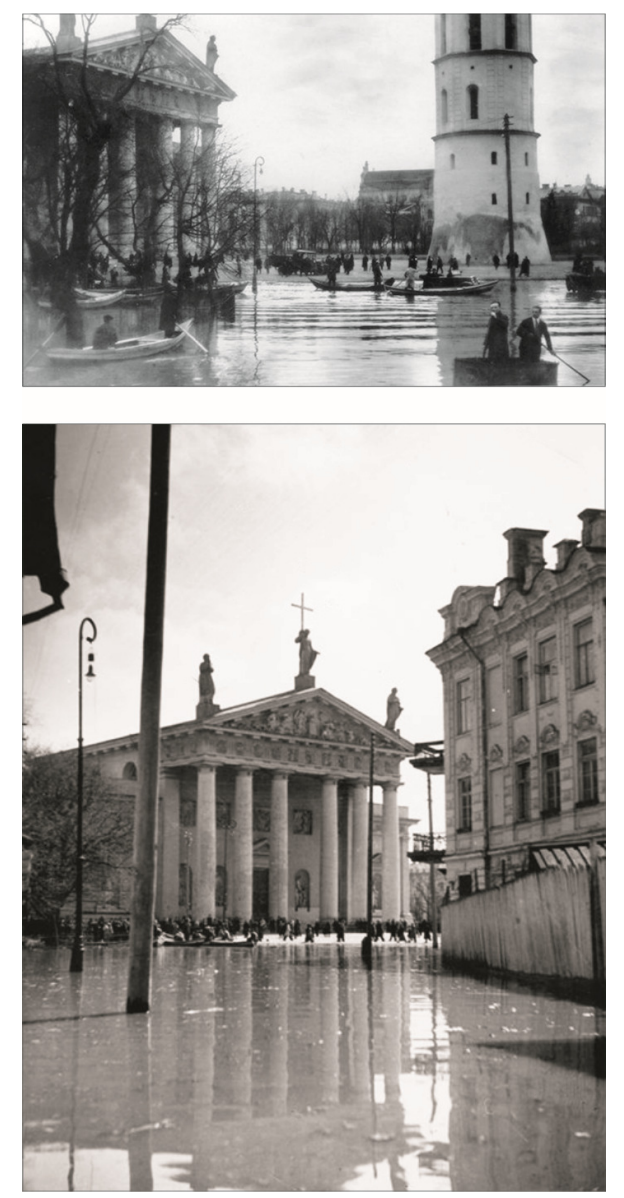

Fig. 8. The Cathedral Square during the flood of 1931 (photo from Narodowe archiwum cyfrowego 2016) 

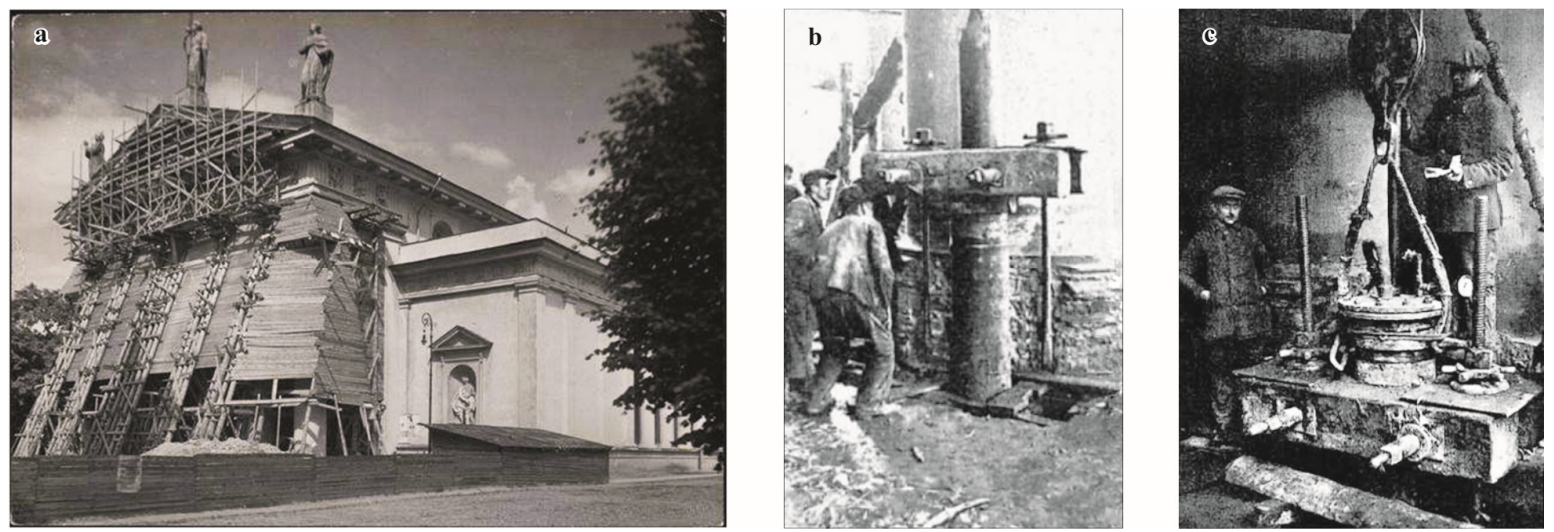

Fig. 9. Reinforcement of the Cathedral foundation (a). Pile placing (b, c) (Wąsowicz 1933)

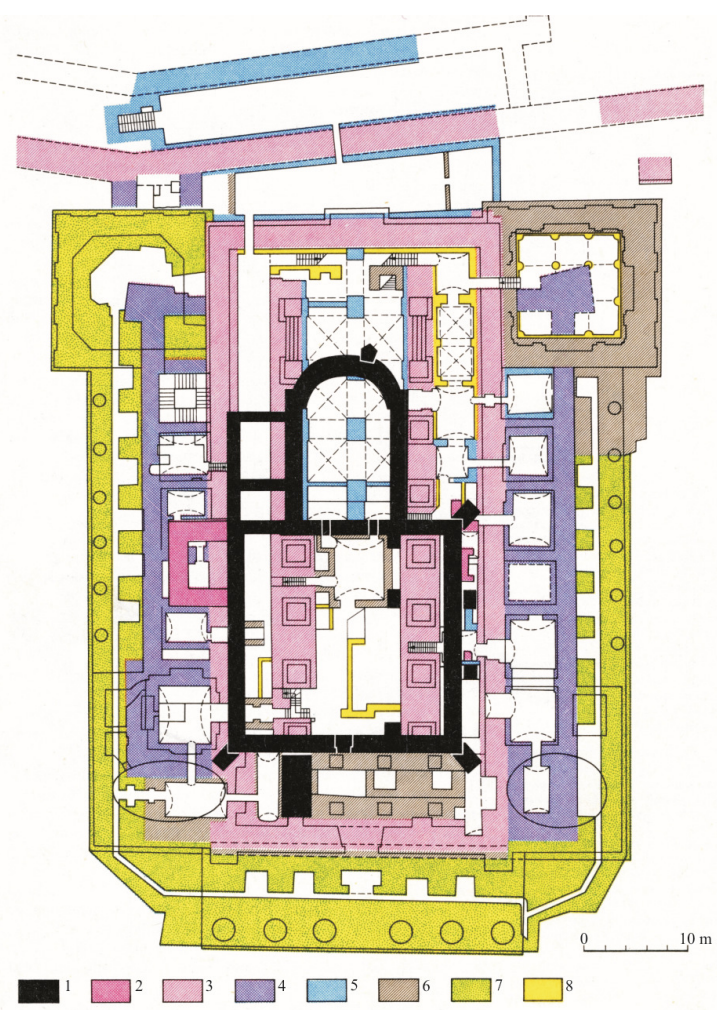

Fig. 10. 1 - remainings of the square building, 2 - the northern wing other chapels of the end of the XIV c., 3 - walls of the Cathedral built after the fire of 1419,4 - chapels built in $\mathrm{XV}-$ the beg. of the XVI, 5 - brick walls of the XVI c. reconstruction, $6-$ St. Kazimieras' Chapel and other brick walls of the XVII-XVIII c. reconstructions, 7 - walls built by L. Stuoka-Gucevičius, 8 - brick walls of the XX c. (according to Kitkauskas 1989)

In 25 years after reconstruction approximately, some walls showed cracks again. In 1963, one more commission was convened under evaluation if the condition of the Cathedral. The commission stated that large vertical cracks occurred in the northern part of the building (especially at the Valavičius' Chapel), smaller ones were observed in other parts of the walls, too.
In 1971, benchmarks were installed in the Cathedral walls and they started measuring settlements of the foundation. Measurements were taken in 1979, 1999, 2003 and 2005. They showed that from 1971 to 2005 subsidence in various parts of the Cathedral foundation was from 3 to $12 \mathrm{~mm}$.

In 1989, when the Reform Movement of Lithuania started, it was decided to rebuild the Palace of Grand Dukes next to the Cathedral. Detailed engineering geological and archaeological studies of the palace were held from 1995 to 1997 . The construction started in 2002.

Upon the order of the Restoration Institute in 2005, research of the Cathedral facade to cover cracks was performed, and it revealed that "The walls and columns of the Cathedral, especially in the north western side, demonstrate features of emergency status, and the reasons for the main deformations and cracking is masonry of various periods without reliable interconnections and incompliance of the foundation with hydrogeological conditions of the area". Other factors of negative impact included "constructions of the Palace of Grand Dukes and intense traffic" (an extract from the research conclusions).

The general history of the Cathedral construction is reflected in the drawing by N. Kitkauskas (1989) (Fig. 10).

At the moment, even though programs of studies of the Cathedral and its observation have been prepared, no researches and works are performed.

\section{Review of engineering geologic researches in the territory of the Cathedral}

The Cathedral has been standing for over 600 years; however, the collection of detailed data on geologic structure of the area, its ground waters, and soils supporting the Cathedral foundation started at the end of the XIX century only. One of more explicit and earliest studies was performed in 1931-1932 when waters of the Neries overflowed the central part of Vilnius and at the same time affected the condition of the Cathedral foundation. Cracks that occurred in the Cathedral made the then government to take care of the Cathedral, which 
resulted in the first ample geological studies of the area. The studies were performed by the company from Warsaw "Raymond", guided by eng. E. Romanskis. Afterwards, Dr. B. Rydzevskis (Bronisław Rydzewski), the Professor of Vilnius University, who joined the research. Eight boreholes, $10 \div 18 \mathrm{~m}$ in depth, were made near the Cathedral; 50 pits, from 1.5 to $8 \mathrm{~m}$ in depth depending on a location, were excavated for the foundation research. The excavation of the pits was accompanied with constant pumping out of ground water and reinforcement of walls. In April of 1932, 9 pits were made near the Cathedral, and there water level was measured three times per day.

In 1958-1959, the scientific-production restoration workshop executed detailed studies of the former Palace of Grand Dukes near the Cathedral. The survived foundation and soil underneath were measured.

In 1970, the Institute for Monuments Restoration performed some archaeological and engineering geological studies of the Cathedral. Over 10 pits were excavated outside the Cathedral and in the basement and there were provided details on distribution of organic soils.

The majority of engineering geological information was received after engineering geological researches of the specialists of the Institute of Site Investigations (K. Monstvilas, A. Kartavičius).

The largest and most explicit engineering geological studies in the territory of the Cathedral were performed in 1968-1971. For that time, in the Cathedral Square and the area of the Gediminas Castle Hill there were made 156 boreholes ( 7 near the Cathedral) and performed 14 cone penetrations tests ( 9 near the Cathedral); 1 plate load test was performed in a pit next to the eastern side of the Cathedral; in the laboratory, there were carried out 358 tests of physical-mechanical properties, 9 mineralogical and 33 palynological analyses. For the purpose of hydrogeological researches (performance observation of ground water), there were made
22 boreholes, up to $8.5 \mathrm{~m}$ in depth; for the purpose of evaluation of ground water parameters (pumping tests), there were arranged 3 groups of boreholes (two groups of 2 boreholes and one group of 4 boreholes). Additionally, they performed 21 pumping out, and performance observations continued for 11 months. The report delivered 26 engineering geological cross-sections, 6 special geological and hydrogeological maps of the territory. When processing the archival study material, the research soil samples of the studies of 1931-1932 was found in the attics of the Cathedral and its new description was executed.

In 1971-2015 some additional investigations were performed in the Cathedral and near it. Fragmental investigations were carried out in the Capitula Crypt in 2004 in order to evaluate a possibility to prepare expositional museum space in the Cathedral basement. It required additional studies of the foundation and soils. 10 light dynamic probing tests (DPL) were carried out up to a $2.0-3.0 \mathrm{~m}$.

\section{Geomorphology of the territory and formation of the current relief}

The area of Vilnius Castles, with the Cathedral in it, is located in the valley of the Neris River, in the Neris and Vilnia confluence. The Neris crosses the city, and its banks at the Gediminas Castle are in $87 \div 86 \mathrm{~m}$ above the sea level. At this location (between the Šnipiškès Hill and the Hill of Three Crosses), the Neris vale reaches its narrowest point (around $2.5 \mathrm{~km}$ ). The area of Vilnius castles belongs to the slopes of the south-west Sapiegyne hill massif, with the Hills of Three Crosses, Gediminas Grave, and Table (Stalas) (altitude $164 \div 163 \mathrm{~m}$ ), the Gediminas Castle Hill on the other side of the Vilnia (altitude $140 \div 141 \mathrm{~m}$ ) and the Cathedral in the foot (Fig. 11).

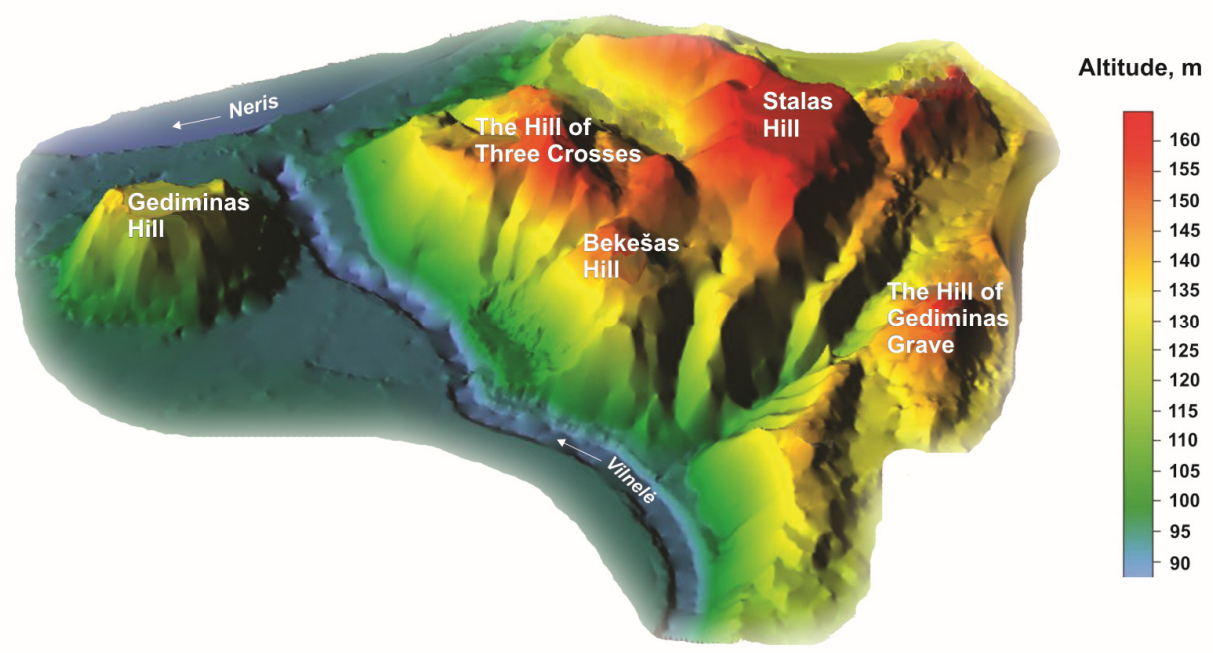

Fig. 11. Model of the Reserve of Vilnius castles. Prepared by A. Murnikova, LGT based on topographic data (Guobyte 2007) 


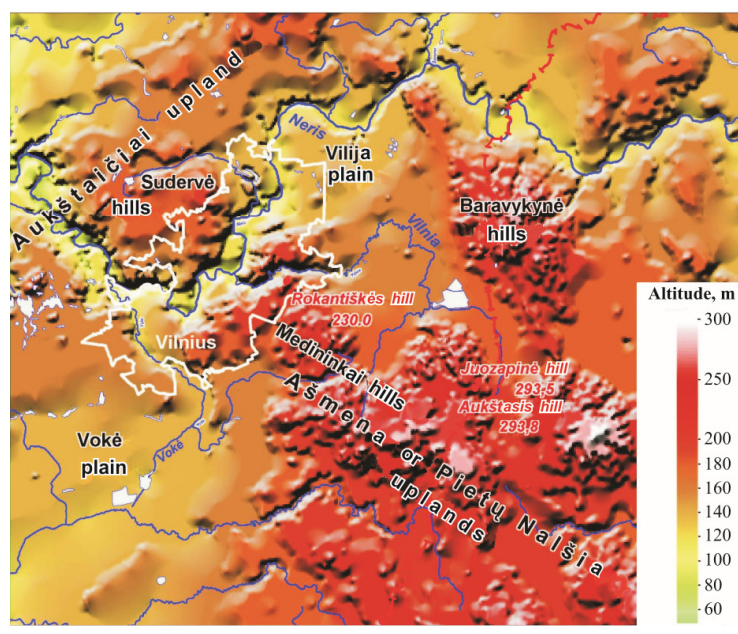

Fig. 12. Maximum extension of the Nemunas glaciation in Vilnius area (Guobyte 2007)

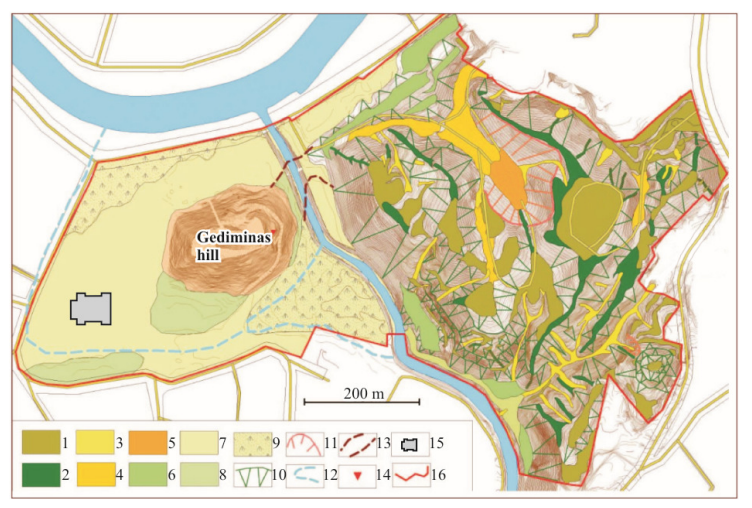

Fig. 13. A geomorphological map of the Vilnius Castles area (Guobyte 2007): 1 - top of the erosional hill, 2 - erosional remnant, 3 - bottoms of ravines and gullies, $4-$ dry valleys bottom, 5 - bottom of the thermoerosional circus, $6-3$-rd and 4-th terraces above flood plain, $7-2$-nd terrace above flood plain, 8 - undulating surface of the 2-nd terrase, 9 - boggy depression, 10 - erosional slope, 11 - slope of the thermoerosional circus, 12 - ancient watercourse of the Vilnia River (according Getkand and Grunert 1648), 13 - a saddle possibly connecting The Gediminas Castle Hill with the hilly massif of the Three Crosses, 14 - locality of active landslides on the slope of The Gediminas Castle Hill, 15 - Vilnius Cathedral, 16 - boundary of the Reserve

Vilnius is located in the edge of the last glacier (Nemunas). This glacier moved 25-21 thousand years ago covering the whole territory of Lithuania and stopped at the location of the present Vilnius. When the edges of the glacier started intensively melting, the formation of the Vilnius hill massif began (Guobyte 2007). The current view of the erosive hills of Vilnius formed approximately 14-15 thousand years ago, together with the Neris valley where the watercourse appeared in the level of 3-rd and 4-th terraces. To these terraces, namely, the mouths of many gullies and ravines open. When ravine erosion suppress, the slopes formed. Boggy depressions were covered in the surface of the second Neris overflood terrace surrounding the Gediminas Castle Hill.

The key factor that determined the formation of the upper part of geologic environment of the territory of Vilnius City is continental glaciation, its extension and recession. In the discussed territory, there can be traced three signs of glaciers occurring in different periods moraines. These are brown grey till clays, sandy clays and till sandy clays (loamy and sandy soils) with admixtures of gravel and boulder. Additionally, interglacial sediments formed during glaciation and deglaciation. Here, sediments of deglaciation flows and extraglacial water melting basins occurred, expressed with formations of sand of various grains, silt and clay. These formations were covered with glacier not once; thus, these are consolidated, dense and stiff enough and show low compressibility.

Processes of glaciation and deglaciation in the Baltic stage are the determinant forming the natural relief and sediments in the surface part. The maximum area of glacier of this stage is to NW from Vilnius city and creates the hill massif of Suderve. The hill massif of Medininkai, formed during the later glaciation and occurring in the south-eastern part of the city, was not covered with the glaciation of the Baltic stage. The intermediate area formed between the mentioned formations through which deglaciation waters from the melting Baltic glacier was flowing from NE to EW. Melting waters were carrying and laying sand and gravel. This lowered stripe became the valley of the old ages Neris where with deepened watercourse and its meandering, there formed 7 overflood terraces. At the same time, there also formed the Vilnia valley where according to the latest data 7 terraces as well are traced (Fig. 12).

When the river valley was forming in the southeast of Vilnius, erosion resulted in erosional hill massif where the Gediminas Castle Hill is one of erosional hills. The valleys of Neris and Vilnia deepened, and waters of these rivers washed out and crossed moraine and intermoraine (intertill) sediment layers and reached Dainava-Žemaitija intermoraine (intertill) sediments. When the water-course erosion slowed down, the Vilnia again repeated the stage of the lateral erosion. As a result, in the pre-delta and delta parts there started winding of the water-course and formed old riverbeds. Sandy clayey sediments lay with admixtures of an organic substance and inserts, as well as peat. Natural relief and its sediments were formed this way (Fig. 13).

When discussing the relief of the Catedral environment, it is essential to distinguish between the modern and earlier natural relief (Fig. 14).

The modern relief of the territory is a consequence of engineering economic activity of a human being. It is of an insignificant stepped type. The current altitudes vary in the range of $93 \div 94.7$ meters. The relief changed many times. The construction of the Lower Castle, territorial acquisition and other works surely required rising of boggy location. Historical resources point out that in 


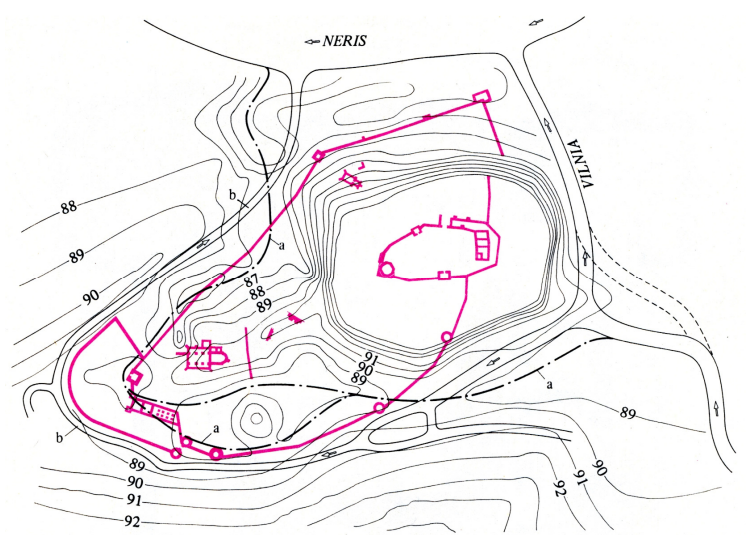

Fig. 14. Reconstruction of the initial ground surface of the Lower Castle: a-supposed location of the old watercourse of the Vilnia River, $b$ - the left watercourse of the Vilnia River according to 1740 Fiurstenhof's plan. Numbers indicate altitudes of the initial ground surface (Kitkauskas 1989)

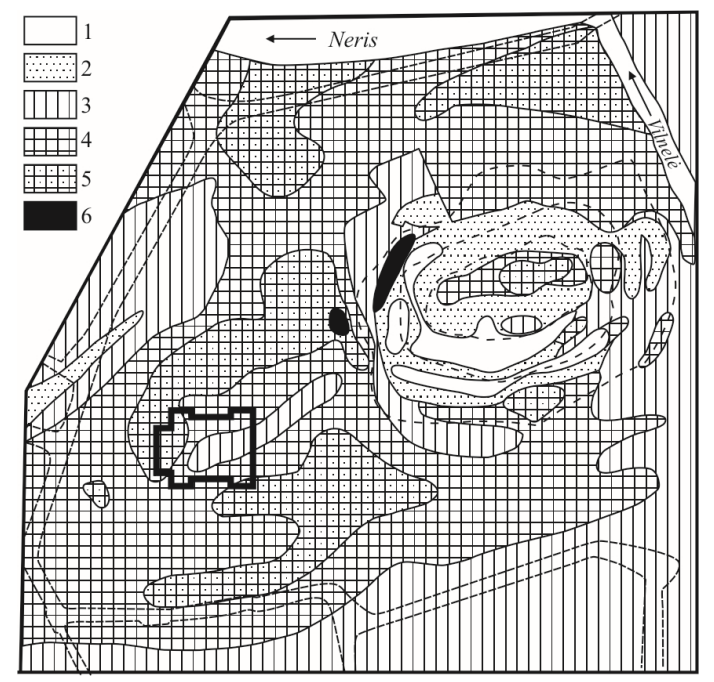

Fig. 15. The map of the thickness of technogenic and bog sediments of the studied territory (acc. Monstvilas 1976):

$1-<1 \mathrm{~m}, 2-1 \div 2 \mathrm{~m}, 3-2 \div 4 \mathrm{~m}, 4-4 \div 6 \mathrm{~m}, 5-6 \div 8 \mathrm{~m}, 6->8 \mathrm{~m}$

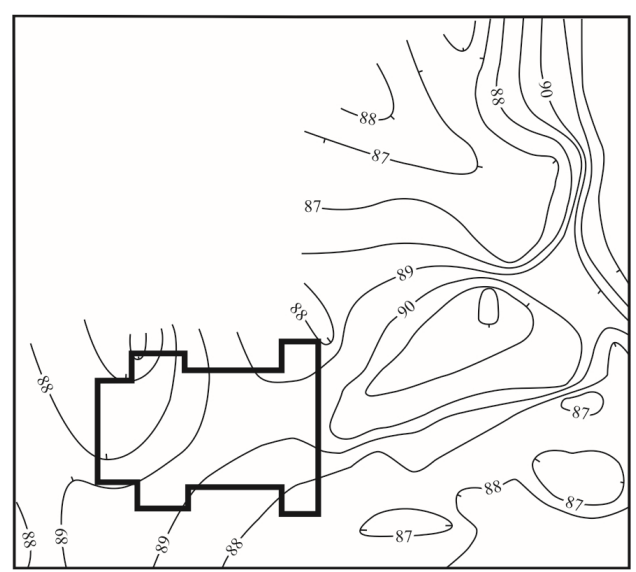

Fig. 16. Hypsometric chart (isolines, altitude, $\mathrm{m}$ ) of the ridge of strong soils (intermoraine sediments) - the bottom of weak soils
1816-1817 the ground surface was meaningfully heightened and levelled. The later reconstructions in 1902, 1940, 1998-2000 caused multiple changes of relief, too.

From the engineering geological point of view, restoration of the natural relief is more significant. Considering the data of researches between the wars and after war, it could be stated that the initial relief is complicated. The relative heights differ up to $4 \mathrm{~m}$ in average. The territory distinguishes with a heightening of the old relief, several meters in length $(2 \div 3 \mathrm{~m})$, going from NE to SW and lowering towards south west till the southwestern corner of the Cathedral. This geomorphological element is diversified with erosive forms. Supposedly, these can be ravines or gullies. These depressions are seen in the southwestern corner of the Cathedral (the St. Kazimieras' Chapel) and in the northeastern corner (the sacristy), also in the north-western (the Valavičiai and Vladislovas Chapels) and in the western sides of the Cathedral. All these erosive forms are filled with various and weak soils. The map of the thickness of technogenic sediments of the Vilnius castle area, prepared by K. Monstvilas in 1976, is given in Figure 15.

\section{Geological structure of the territory and properties of its soils}

The geological cross-section of the area consists of technogenic soil (tIV), boggy sediments and cultural layer (k-bIV), alluvial sediments (aIV), DainavaŽemaitija intermorain sediments (lIIbt) (Figs 17, 18, 19).

The layer of technogenic soils (tIV) around the Cathedral was mainly formed in the first half of the XIX century. This is, for the greater part, brick detritus, humous sandy soil, mixture of sand and gravel with different domestic waste. The thickness of soils is from 1.5 to 4.5 metres. These soils form a kind of shell around the Cathedral and are not directly used as the basis under the foundation.

Cultural and boggy sediments (k+bIV) are enriched with different domestic waste of the cultural layer and occurs under the layer of technogenic soil up to $4.5 \div 8.5$ metres in depth. They spread in the whole territory of the Cathedral, except for the eastern and central parts. Their thickness varies from 1.5 to 4.5 metres. The thickest part is at the north-western corner of the Cathedral. According to the structure, these are peaty sandy clays and peat with admixture of domestic waste. The unit weight of sediments is $9 \div 12 \mathrm{kN} / \mathrm{m}^{3}$, void ratio is $0.8 \div 1.9$, moisture content $24 \div 29 \%$, cone resistance $-1 \div 2 \mathrm{MPa}$. The soil is loose, weak.

Alluvial sediments (aIV) contain sand gravel, sands of various coarseness, and sandy loam in rare cases. These sediments are widely spread in the whole area of the Cathedral, except for the north-western corner. They are found in the depth of $3.5 \div 6.8$ metres. The ridge of the layer goes up in the eastern side of the $\mathrm{Ca}$ thedral. The unit weight of soils is $18 \div 21 \mathrm{kN} / \mathrm{m}^{3}$, cone 


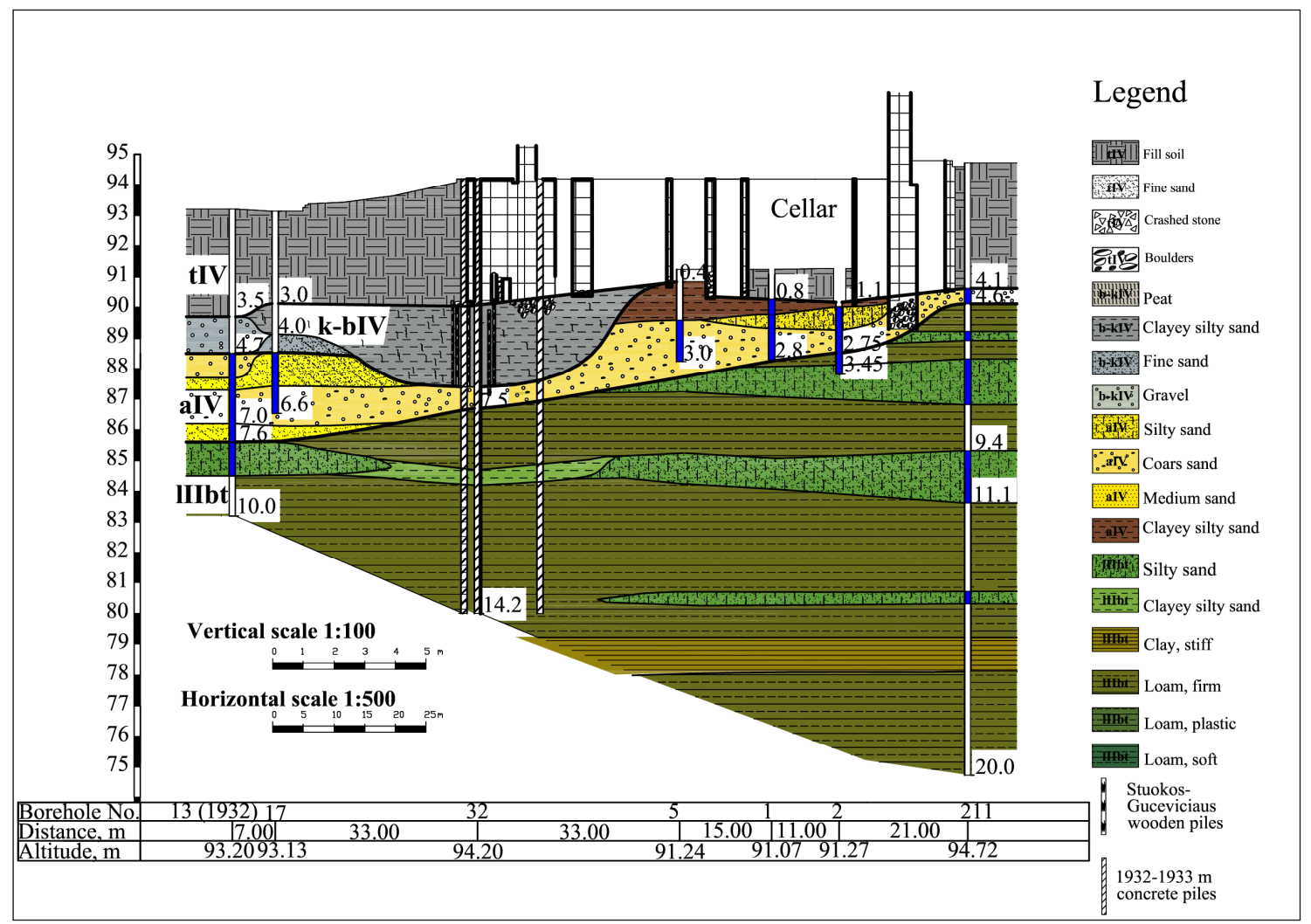

Fig. 17. Engineering geological cross-section II-II under the Cathedral (according to Monstvilas 1973)

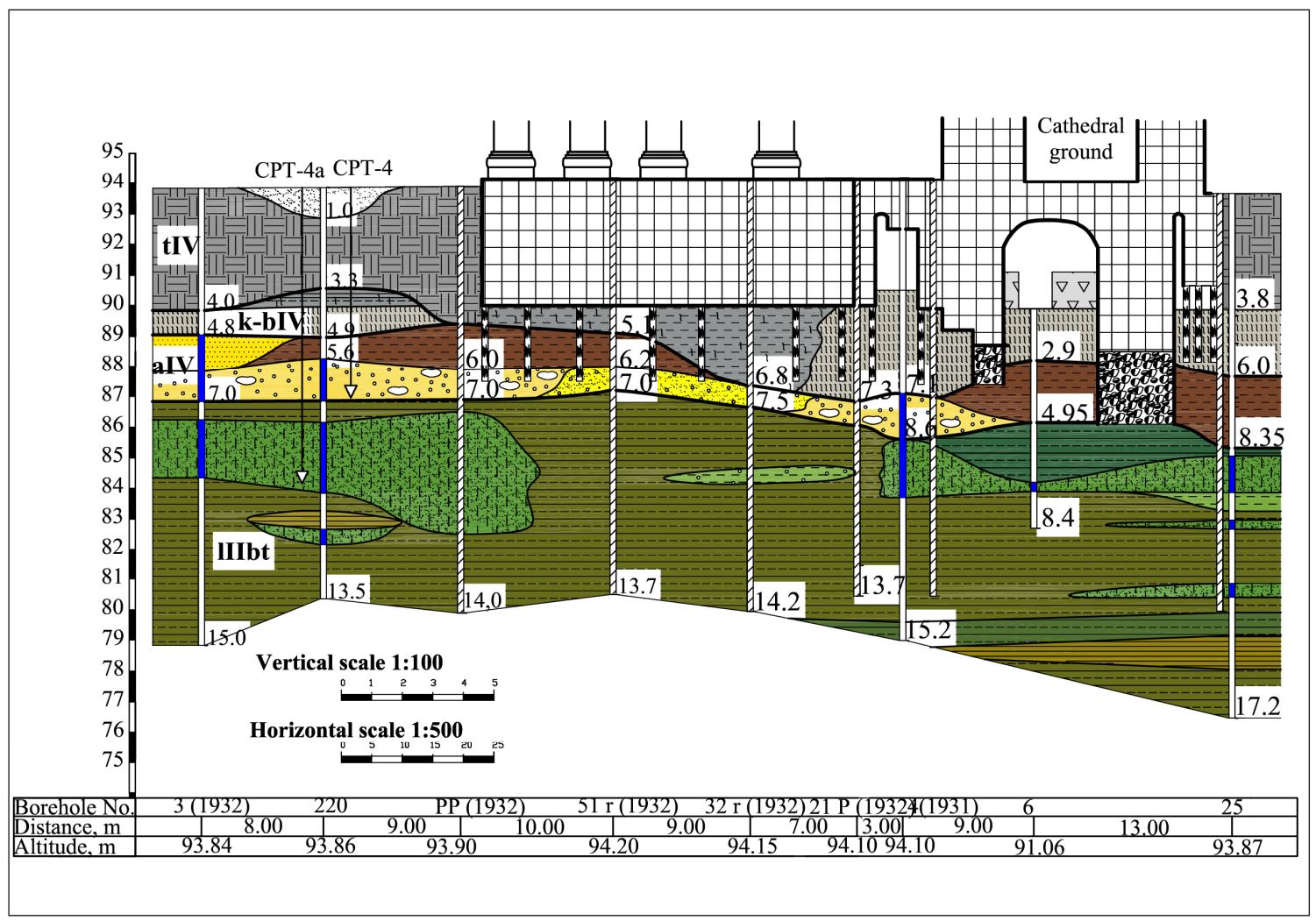

Fig. 18. Engineering geological cross-section VI-VI under the Cathedral (according to Monstvilas 1973) 


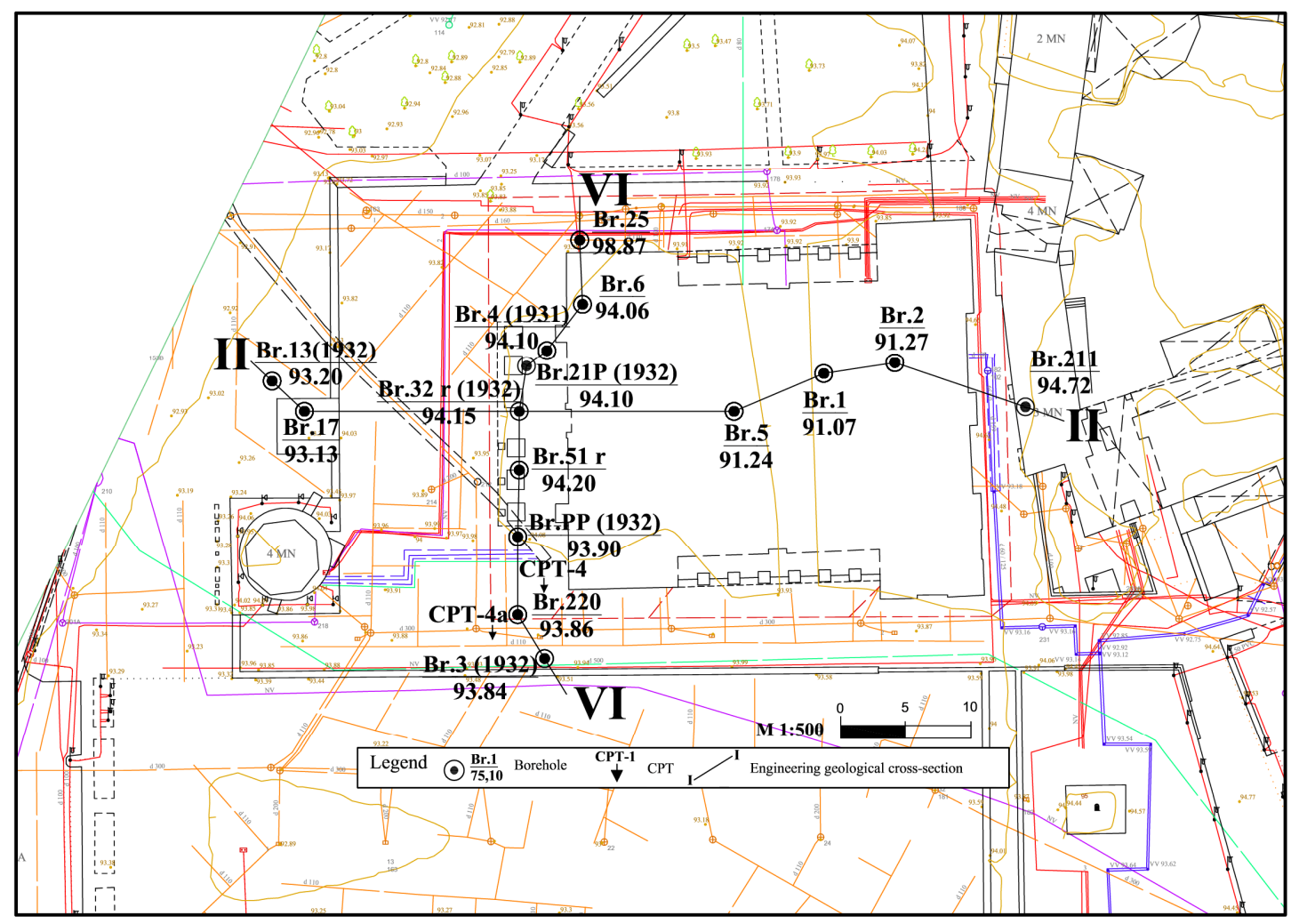

Fig. 19. The plan of research points

resistance $-5 \div 10 \mathrm{MPa}$. The soil is appropriate basis for the foundation.

The main socle for younger sediments consists of Dainava-Žemaitija intermoraine sediments (Fig. 15). From the point of view of lithology, these sediments may be divided into two complexes: the upper one sandy silt and the lower one - clayey silt. The mean value of void ratio of the first complex is 0.56 , cone resistance $-16 \mathrm{MPa}$. The unit weight of the second complex is $19 \div 20 \mathrm{kN} / \mathrm{m}^{3}$, cone resistance $-9 \div 14 \mathrm{MPa}$. The soil is dense, strong, and of low compressibility. The total bored thickness of this layer is over 22 metres. The plan of depth of occurrence of intermoraine sediments (Monstvilas 1976) is given in Figure 16.

These sediments, in particular, become a reliable basis for the foundation of old cathedrals, as well as a basis for reinforced piles built after reinforcement works in 1931. Geotechnical properties of soils under the Cathedral are given in Table 1.

\section{Hydrogeological conditions}

Ground water occurs in alluvial sand and gravel and in the lower part of the cultural layer and boggy sediments. The lower confining bed consists of Dainava-Žemaitija sediments. The confining bed is relative. The average depth of confining bed occurrence is $8 \div 10$ metres. The depth of ground water depends on a season of the year. At the end of February and at the beginning of March it is in the depth of $4.0 \div 4.5 \mathrm{~m}$. The highest level is reached in April and May. Within this period the depth of ground water is $3.0 \div 3.5 \mathrm{~m}$. The maximum amplitude of fluctuations is around $1.5 \mathrm{~m}$.

In the past, floods of the Neris River were a relevant factor for the level of ground water. M. Knakfus mentions that even before the works started by Stuoka Gucevičius the Cathedral basement was overflooded. How was the water removed? Some hints are given by M. Homolicki in the review of the history of Vilnius city written by J. I. Kraszewski in 1842: "when placing elder piles for foundation of new walls, he (Gucevičius - auth.) built of bricks two deep canals: one starting under the St. Kazimieras' Chapel, the other under the sacristy. The canals surround the Cathedral from both sides and proceed under the lateral galleries and along border walls of corner oval chapels. The canals serve not only for water draining from flooded basement where it slowly amasses but also collect spring waters and waters from several underground sources, one at the southern side porch of the foundation of the former Chapel of St. Trinity, the rest two or three sources of very pure water spout under the sacristy and under the northern lateral nave in its eastern end. Water of these sources is drained to the northern lateral canal. A well dug some time ago in one of the basements was also used for this purpose. The water collected here has a light smell of sulphur, just like the spring water in the northern (eastern?) side of the Castle Hill. Today this well is hidden under silt. When reaching the portico, the northern lateral canal turns to the south, goes under the 
Table 1. Geotechnical properties of soils under the Cathedral

\begin{tabular}{|c|c|c|c|c|c|c|c|c|c|c|c|}
\hline \multirow{2}{*}{$\begin{array}{l}\text { Geo- } \\
\text { logical } \\
\text { age }\end{array}$} & \multirow{2}{*}{$\begin{array}{l}\text { Name of } \\
\text { soil (by } \\
\text { GOST) }\end{array}$} & \multirow{2}{*}{$\begin{array}{l}\text { Thick- } \\
\text { ness of } \\
\text { layer, } \\
\text { m }\end{array}$} & \multicolumn{8}{|c|}{ Geotechnical properties* } & \multirow[t]{2}{*}{ Conclusions } \\
\hline & & & $\begin{array}{c}\rho, \\
\mathrm{g} / \mathrm{cm}^{3}\end{array}$ & 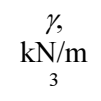 & $e$ & $\begin{array}{l}w, \\
\%\end{array}$ & $\begin{array}{c}c, \\
\mathrm{kPa}\end{array}$ & $\begin{array}{c}\varphi \\
\text { deg. }\end{array}$ & $\begin{array}{c}q_{c}, \\
\mathrm{MPa}\end{array}$ & $\begin{array}{c}E, \\
\mathrm{MPa}\end{array}$ & \\
\hline \multirow{3}{*}{$\begin{array}{l}\text { Tehno- } \\
\text { genic } \\
\text { soil, } \\
\text { tIV }\end{array}$} & $\begin{array}{l}\text { Sandy } \\
\text { loam }\end{array}$ & \multirow{3}{*}{$1.5 \div 4.5$} & 1.93 & $14 \div 16$ & 0.47 & $8.7 \div 14.6$ & 8 & 24 & $1 \div 2$ & $3 \div 6$ & $\begin{array}{l}\text { Weak soil } \\
\text { loose }\end{array}$ \\
\hline & $\begin{array}{c}\text { Clayey } \\
\text { loam }\end{array}$ & & 2.02 & $14 \div 16$ & 0.51 & $6.4 \div 14.4$ & 12 & 25 & $1 \div 2$ & $3 \div 6$ & \\
\hline & Sand & & 1.65 & $12 \div 15$ & 0.71 & $5.8 \div 8.5$ & 2 & 32 & $2 \div 3$ & $6 \div 9$ & \\
\hline $\begin{array}{l}\text { Culture } \\
\text { and } \\
\text { boggy } \\
\text { depos- } \\
\text { its, } \\
\text { K+bIV }\end{array}$ & $\begin{array}{l}\text { Sandy } \\
\text { loam with } \\
\text { organic, } \\
\text { peat }\end{array}$ & $1.5 \div 4.5$ & $0.9 \div 1.69$ & $9 \div 12$ & $0.8 \div 1.9$ & $24 \div 29$ & - & - & $1 \div 2$ & $3 \div 6$ & $\begin{array}{l}\text { Weak soil, } \\
\text { loose (Organic } \\
\text { content } \\
\mathrm{I}_{\mathrm{om}}=10 \div \\
70 \%)\end{array}$ \\
\hline \multirow{3}{*}{$\begin{array}{l}\text { Alluvi- } \\
\text { um } \\
\text { depos- } \\
\text { its, } \\
\text { aIV }\end{array}$} & $\begin{array}{l}\text { Cobbles } \\
\text { and gravel }\end{array}$ & \multirow{3}{*}{$3.5 \div 6.8$} & 2.09 & $18 \div 21$ & 0.59 & - & 1 & 40 & $5 \div 10$ & 40 & \multirow{3}{*}{$\begin{array}{c}\text { Dense gravel } \\
\text { and sand, low } \\
\text { compressibil- } \\
\text { ity, firm and } \\
\text { plastic clayey } \\
\text { loam and silty } \\
\text { loam }\end{array}$} \\
\hline & Sand & & $1.92 \div 2.02$ & $19 \div 20$ & $0.61 \div 0.76$ & - & $1 \div 7$ & $29 \div 40$ & - & $18 \div 40$ & \\
\hline & $\begin{array}{l}\text { Clayey } \\
\text { loam and } \\
\text { sandy } \\
\text { loam }\end{array}$ & & 1.83 & 18 & $0.71 \div 0.93$ & $27 \div 31$ & 11 & 19 & - & 10 & \\
\hline \multirow{2}{*}{$\begin{array}{c}\text { Inter- } \\
\text { moraine } \\
\text { deposits, } \\
\text { lIIbt }\end{array}$} & $\begin{array}{l}\text { Fine and } \\
\text { silty sand }\end{array}$ & $3 \div 13$ & $1.76 \div 1.81$ & $17 \div 18$ & $0.56 \div 0.61$ & $3 \div 6$ & $20 \div 24$ & $34 \div 40$ & 16 & $43 \div 45$ & $\begin{array}{l}\text { Dense soil, low } \\
\text { compressibility }\end{array}$ \\
\hline & $\begin{array}{c}\text { Sandy loam, } \\
\text { silty clayey } \\
\text { loam, varvic } \\
\text { clay }\end{array}$ & $>10$ & $1.89 \div 2.0$ & $19 \div 20$ & $0.59 \div 0.78$ & $13 \div 32$ & $22 \div 58$ & $27 \div 29$ & $9 \div 14$ & $45 \div 55$ & $\begin{array}{l}\text { Stiff and very } \\
\text { stiff soil, low } \\
\text { compressibility }\end{array}$ \\
\hline
\end{tabular}

Note: ${ }^{*} \rho$-density, $\mathrm{g} / \mathrm{cm}^{3} ; \gamma-$ unit weight, $\mathrm{kN} / \mathrm{m}^{3} ; e$ - void ratio; $w$ - moisture content, $\% ; c$ - cohesion, $\mathrm{kPa} ; \varphi-$ angle of internal friction, degree; $q_{c}$ - cone resistance, MPa; $E$ - modulus of deformation, MPa.

portico and connects to the southern lateral canal at the corner of the Chapel of St. Jonas Nepamukas. Here a bigger, one hundred steps in length, round collector is formed, and it obliquely connects to the main underground city canal, close to its tributary into the Neris River. For water could easily flow through the Cathedral canal, L. Gucevičius built the collector bottom two feet $(65 \mathrm{~cm})$ higher than the bottom of the city canal at the place of the tributary to it. For this reason, the church basements were extremely dry more than several years after the Cathedral restoration and consecration. However, in 1816 and 1817, when boulevards and walking paths were built in the Cathedral square, its surroundings and banks of the Neris, the ground surface was substantially lifted; the main city canal was also remade from wooden to brick one, and simultaneously, its level was lifted so that its bottom appeared at a feet $(32.5 \mathrm{~cm})$ higher than the bottom of the church collector in the place of its tributary. Therefore, the collector water cannot fully go to the city canal and stays in the collector, and during stronger rains, spring flood season or floods of the Neris the city canal waters immediately flood the Cathedral collector and its canals, as we could personally witness this. In such cases the Cathedral basements, first those under the lateral northern and middle nave to the capitula choir are fully covered with water. Water mainly collects under the Chapel of "Valavičiai" (according to Drèma 1991). It is possible these are the main reasons why the basements of the Cathedral are flooded.

To prevent the Cathedral basement from being flooded, ground water lowering has been performed in the eastern part (the capitula crypt) since 2003. There were drainage systems built at the altitudes of $89.85 \mathrm{~m}$ altitude, and pumping out altitudes was even lower. No observational boreholes were made.

Changes of levels of ground water is dependent on the change level of the Neris and Vilnia, changes of the watery level of the prequaternary watering-place in the Bernardinai Garden and likely water getting from underground communications.

\section{Geological and anthropogenic processes}

Based on the existing research material no geological processes are observed; however, the general evaluation of geological environment allows the assumption about likeliness of some geological processes. The found 
lenses of an organic substance and interlayers and the change of the level of ground waters precondition possible destruction of the organic substance. This process, as the world practise shows, may continue for centuries and result in deformations of the building constructions. Another reason for deformations could be solifluction of sandy silt soils, i.e. removing of particles and occurrence of voids under the foundation due to fluctuations of ground water level and drainage. Still, these presumptions require additional researches.

Observations of settlements in the walls of the Cathedral started in 1971 and continued till 2005. The layout of marks of observations in the walls of the Cathedral is given in Figure 20. The picture highlights only those marks that reveal the largest depressions. The sacristy undergoes the biggest deformations (29-38 marks). Here depressions reach from 2 to $10 \mathrm{~mm}$. Depression in the middle of the southern wall (9-10 marks) is up to $7 \mathrm{~mm}$ and in the northern corner of the portico (54-57 marks) reaches up to $4.5 \div 6.5 \mathrm{~mm}$. (Fig. 21).

The Cathedral and surrounding territory gets into the oldest area of Vilnius waterfield. This waterfield uses confined underground water occurring in the depth of $30 \div 32 \mathrm{~m}$ (the Sereikiškès Park). The distance from the watering-place to the Cathedral is around $620 \mathrm{~m}$. The maximum water level lowering happened in 19591960 and reached approximately $10.5 \mathrm{~m}$. According to the calculations of K. Dundulis et al. (2002), upon such cone of depression, the ground surface depression at the Cathedral Square could be around $3 \mathrm{~cm}$ (Fig. 22).

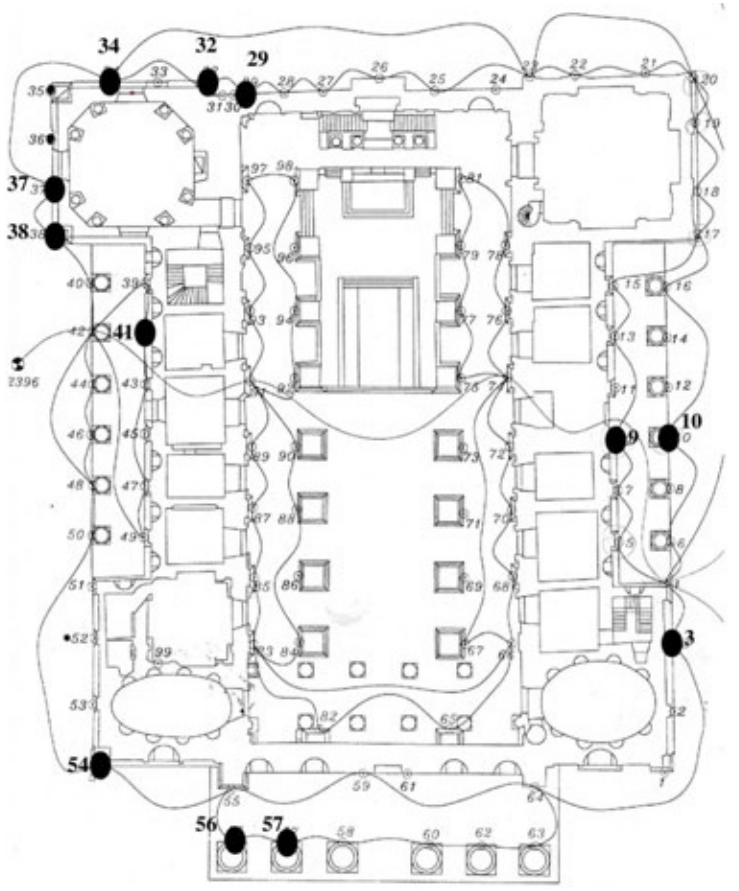

Fig. 20. Layout of marks of the Cathedral (Garška 2005)

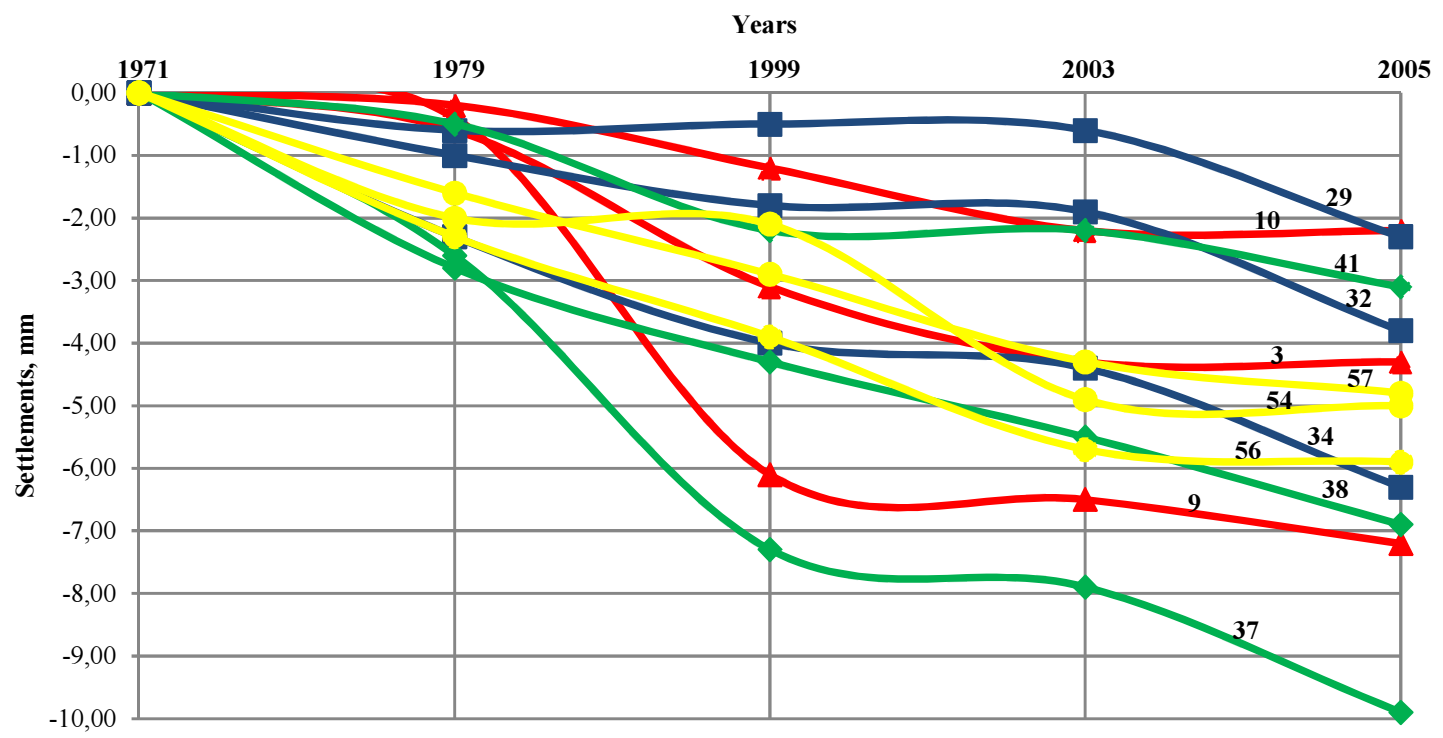

Fig. 21. Settlements of the walls of the Cathedral (mm): red - the southern wall, blue - the eastern wall, green - the northern wall, yellow - the western wall, the portico. 29 - mark number (according to Garška 2005) 


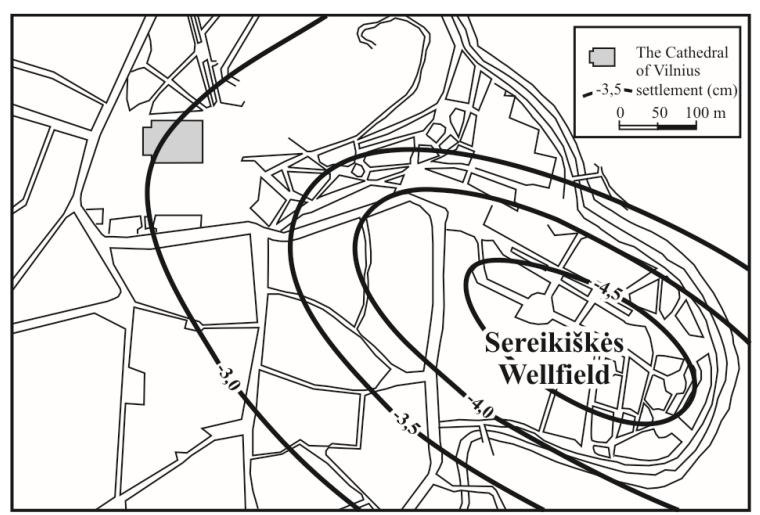

Fig. 22. The plan of the ground surface depression affected by the Sereikiškees water-place (Dundulis et al. 2002)

\section{Conclusions}

- Reconstruction of the Vilnius Cathedral, planned extension of its location resulted in usage of different geological layers for supporting the basement, different kinds of foundation and depth of their layers, which caused previous and still continuing deformations.

- The earlier waters of the Neris floods and fluctuations of ground water level had a negative impact on both the foundation and conditions of the basis.

- The earlier and current impact of active people deeds (construction works performed and under performance, intense and still growing traffic near and in the area, influence of the wateringplace nearby) even if not significantly but, still has an impact of the Cathedral deformations.

- To secure further operation of the Cathedral, it is essential to constantly observe deformations of the building, carry out additional geotechnical researches, and, if necessary, to perform reinforcement of the foundation and other constructions.

\section{References}

Drema, V. 1991. Vilniaus Šv. Onos bažnyčia. Vilniaus Katedros rekonstrukcija 1782-1801 metais. Vilnius: Mokslas.

Dundulis, K.; Gadeikyte, S.; Medzvieckas, J. 2002. Technogeninès mechaninès apkrovos poveikio geologinei aplinkai ịvertinimas, Litosfera (6): 77-81.
Dundulis, K.; Trumpis, G. 2015. Vilniaus arkikatedros geologinès sąlygos ir jų raida, iš Pranešimas konferencijoje „Vilniaus arkikatedros tarpukario tvarkybos darbai ir nüdienos aktualijos", 2015 m. lapkričio 6 d., Vilnius, Lietuva.

Garška, Z. 2005. Vilniaus arkikatedros sédimu stebejjimo 10ciklo technine ataskaita. UAB ,Inžineriniai tyrinejjimai“ filialas ,Inžinerinè geodezija“, Vilnius.

Guobytè, R. 2007. Vilniaus pilių teritorijos egzotiškasis reljefas ir gelmių sandara, Lietuvos pilys: 24-35.

Kitkauskas, N. 1970. Paveikslų galerijos (buv. Vilniaus Katedros) konservavimas 1931-1937 m. ir šiandieninès jos deformacijos, Architektūros paminklai 1: 15-43.

Kitkauskas, N. 1989. Vilniaus pilys, statyba ir architektūra. Vilnius: Mokslas.

Metalo forma. 2016. Paveikslai istorine tematika [online], [cited 08 February 2016]. Available from Internet: http://www.metaloforma.lt/home?cat=25

Monstvilas, K. 1973. Gedimino kalno sutvarkymas. Gedimino klano ir Katedros aikštès inžineriniai geologiniai tyrinèjimai. Ataskaita T. I-III. Geologijos I skyrius. Inžinerinių tyrinėjimų institutas, Vilnius.

Monstvilas, K. 1976. Vilnios žiočių geologija ir geomorfologija, Geografinis metraštis 14: 183-197.

Monstvilas, K. 1997. Vilniaus Katedros ir Valdovų rūmų pamatai: jų pagrindo tyrimai, Geologijos akiračiai (4): 21-26.

Monstvilas, K.; Trumpis, G.; Kitkauskas, N. 1995. Foundations of Vilnius Cathedral and of the Duke's Palace and the investigations of their ground, in $8^{\text {th }}$ Baltic Geotechnical Conference, 2-5 October 1995, Vilnius, Lithuania, 5-9.

Narodowe Archiwum Cyfrowego. 2016. Zbiory NAC on-lineprototyp [online], [cited 08 February 2016]. Available from Internet: https://audiovis.nac.gov.pl

Pečkaitis, A. 2004. Arkikatedros kapitulos kriptos inžineriniai geologiniai tyrinejimai. Ataskaita. UAB „Geostatyba“, Vilnius.

Satkūnas, J.; Mikšys, R. B.; Mikulènas, V.; Minkevičius, V. 2008. Geodinaminiai procesai Vilniaus pilių teritorijoje: šlaitų deformacijos, Lietuvos pilys: 62-68.

Turisto pasaulis. 2016. Vilniaus katedros varpine - lankytina vieta [online], [cited 08 February 2016]. Available from Internet: http://www.turistopasaulis.lt/vilniaus-katedrosvarpine/\#.VweXQzFfv_B

Wąsowicz, H. 1933. Prace nad umocnieniem fundamento bazyliki Wilenskiej, Architektura $i$ Budownictvo (6): 167-178. 